\title{
A COMPARATIVE STUDY OF THE STATUS OF CITIZENSHIP RIGHTS IN IRAN AND BRITAIN
}

UM ESTUDO COMPARATIVO DO STATUS DOS DIREITOS DE CIDADANIA NO IRÃ E NA INGLATERRA

Khadijeh Solh Mirzaee ${ }^{1}$

Hamideh al-sadat Sadat Akhavi ${ }^{2}$

\begin{abstract}
The subject of this paper is "A Comparative Study of the Status of Citizenship Rights in Iran and England." Citizenship rights are from modern concepts and from the devices of democratic life of individuals in a political society. Citizenship rights have been an important and indisputable right in human history in the historical era, and for which the principles and basics have been considered. Citizenship rights in Iranian and British law include civil, social, political and judicial rights, and each of these countries has the means and tools to enforce these rights. In this paper, it has been tried to prove that humans have their own deserving rights and, accordingly, they need assignments. Identifying and defining these assignments and rules for the human's social life is a basic tool. Another objective of this study is to compare the types of citizenship rights in accordance with the rights of the United Kingdom and Iran. The research method is descriptive-analytical, and its data has been compiled as documentary and library studies.
\end{abstract}

Keywords: Citizenship Rights; Iran; Britain; Civil Rights; Social Rights; Political Rights; Judicial Rights.

\section{Resumo}

O assunto deste artigo é "Um estudo comparativo do status dos direitos de cidadania no Irã e na Inglaterra". Os direitos de cidadania são de conceitos modernos e dos dispositivos da vida democrática dos indivíduos em uma sociedade política. Os direitos de cidadania têm sido importantes e indiscutíveis na história da humanidade na era histórica, e para os quais os princípios e bases foram considerados. Os direitos de cidadania na lei iraniana e britânica incluem direitos civis, sociais, políticos e jurídicos, e cada um desses países têm os meios e ferramentas para fazer valer esses direitos. Neste artigo, tentou-se provar que os seres humanos têm seus próprios direitos e, consequentemente, precisam de atribuições. Identificar e definir essas atribuições e regras para a vida social do ser humano é uma ferramenta básica. Outro objetivo deste estudo é comparar os tipos de direitos de cidadania de acordo com os direitos do Reino Unido e do Irã. O método de pesquisa é descritivo-analítico, e seus dados foram compilados como estudos documentais e bibliográficos.

Palavras-chave: Direitos de Cidadania; Irã; Grã-Bretanha; Direitos Civis; Direitos Sociais; Direitos Políticos; Direitos Judiciais.

\footnotetext{
${ }^{1}$ Faculty Member Islamic Azad University, Tehran, Iran. E-mail: hamidesadat.akhani@gmail.com

2 Student of Public Law, Islamic Azad University, Electronic Branch, Tehran, Iran. E-mail: pejman.mahmoodi.g@gmail.com
} 


\section{INTRODUCTION}

Citizenship rights as a subset of public rights are closely related to the basic rights and political and civil liberties of individuals and in recent years has become one of the priorities of the administration of each country. If we consider the law, in general, the necessary rules and regulations that govern the relations of individuals in a society, considering the type of relationship, we can separate two types of private and public rights. When we talk about the citizen and his rights, our law is a set of rights that governs social relations. Citizenship rights, in fact, represent the rights that each person has in the nationality of a country. The importance of citizenship rights is such that they are closely linked to the status of governance, and even some experts believe that a society in which the rights of citizens are not institutionalized, the relationship between the people and the sovereignty is undermined. Guaranteeing the basic rights of the citizens is first and foremost enforced by the inclusion of these rights in the constitution of each country. In other words, the constitution is an effective step in the process of rule of law, guaranteeing freedom and enjoyment of opportunities and realizing citizenship. Protecting and safeguarding the rights of every citizen is the responsibility of all the authorities and government agencies that must act in this regard to take the necessary steps to protect the rights of citizens in all their executive departments in order to override the citizens' rights in formal, administrative and even legal procedures. And if civil rights are not met by government agencies, there should be good judiciary bodies that protect the rights of individuals against the state, observing the principles of fair trial. The inclusion of the fundamental rights of citizens in the constitution and ordinary laws, the necessity of observance of these rights by government agencies, the existence of competent judicial authorities that deal with people's complaints about the violation of their rights by government agencies and the supervision of state agencies in this regard, all of them are among the criteria for the implementation and guarantee of citizenship rights in any democratic society. A comparative study of civil rights standards in the legal system of Iran and England is at the heart of our discussion in this thesis.

\section{Problem statement}

Citizenship rights, as a subset of public law, are closely related to the basic rights and political and civil liberties of individuals and in recent years has become one of the priorities of the administration of each country. One of the components of a desirable community is the 
existence of security and the sense of it in society, which is also referred to as an indicator of the rights of citizenship. One of the vast dimensions of security, is public security and its preservation. Citizenship is one of the derivatives of the city. Citizenship is an advanced form of urbanization. Residents of the city will be promoted to the citizen when they respect each other's rights and act on their responsibilities to the city and community. At the heart of citizenship, it's always a matter of belonging to a community that applies policies and rights. The issue of citizenship rights, the relations of the people of the city, their rights and duties against each other, principles, goals, and tasks and methods of doing them. It can be said that the rights of citizenship are a mixture of the duties and responsibilities of citizens towards each other, the city and the state or the ruling powers and the state, as well as the rights and privileges that the task of securing those rights lies with the ruling powers. Citizens are also responsible for these rights, and recognizing these rights and duties has an important role in promoting citizenship and creating a society based on order and justice.

Rights in the UK, like most other countries in the world, are divided into two categories of public rights that shape relations between citizens and the state, and private rights that shape relationships between individuals and private organizations. But there is also a more important division: the division of rights into civil and criminal law. Under British law, according to the 1981 law, there is little difference between the two terms of citizenship and nationality, except that the term citizenship is used more in domestic law and the term nationality is used more in international law and international relations, because the government has long been endeavoring to curtail gradually the scope of its citizenship laws by citizens of the former and current colonies by abolishing different laws of nationality. The elimination of ambiguities, especially in the context of treaties related to personal status and the rights of citizens, is important, and its necessity is to address that ambiguity. The question we answer in this thesis is: What is the status of citizenship rights and social functions in Iranian and English law? What are the components of the rights of citizenship in Iran and the United Kingdom?

\section{The importance and necessity of research}

In recent years, citizenship rights have become one of the most complex social and political issues, attracting the attention of many thinkers and lawyers. With the events that have taken place in the global system, including the expansion of communications, globalization, multi-culturalism, countries such as Iran and Britain have been influenced by new theories and 
views on citizenship rights, and this necessitates research on the rights of citizens from Political and judicial aspects and the comparison between the two countries. Also, the importance of the issue is because citizenship has become, in a relatively short period of time, an important concept for describing, understanding and explaining the various ways in which members of the community share or are deprived of the development process. In fact, no concept as much as a citizen in human history does not promote the aspirations of human need for equality and their demands for freedom. Therefore, it is imperative to examine the fundamental rights of citizens at all angles of life.

\section{The historical background of the concept of citizenship rights in English law}

The first statement on civil rights aimed at identifying the rights of citizens and reducing the power of the Shah in 1215 in the UK was approved by the English Barons in a collection called Magnakartha. The Patriotic World, whose theory was raised 500 BC by the Greek philosopher Heraclitus, and by the philosophers after him, most notably Kant, was a concept more than its words, and later became the basis of the guarantee of ethical and conscientious performances for human rights and citizenship in a transnational global context. Hence, Greece should be considered the birthplace of citizenship rights (Folex, 2002: 26). One can say that the concept of human rights is often raised alongside the two concepts of "citizenship rights" and "fundamental rights." These three concepts, are used sometimes as synonyms, and sometimes as alternatives to each other, but, in conceptual separation, there are delicate boundaries between these three concepts. Citizenship rights are the constitutive part of the constitution, and only the "national" of each country includes the citizens of the same country, and human rights in an international way include the rights of all people in the world (Oliya, 2011: 182).

\section{The evolution of the concept of citizenship in Iranian and British law}

\section{Developing the concept of citizenship in Iran}

In recent decades, the new word "Citizenship" has been translated into Persian by translation and communication with the West. Of course Medina and civilian concepts have a greater presence in Arabic and Persian languages. In particular, since Abu Nasr al-Farabi (322$247 \mathrm{AH}$ ) formulated his civil philosophy and he set up a new theory in Islamic civilization. In Iran 
and even in the West, before the independence of the United States and the French Revolution, there was no well-documented constitution; there was only one set of ethical and religious recommendations or instructions. Therefore, citizenship is not found in the form of legal and binding texts. In Iranian culture, citizenship has been prosecuted in the form of guidance and advisory texts. In the history and culture of Iran and Islam, the sources of the constitution were called "the covenant ", such as the covenant of Ardeshir, the covenant of Imam Ali (as) and his decree to Malik Ashtar, or the decree of Omar ibn Khattab to Abu Musa Ash'ari, which is considered as an important source of jurisprudence in the Sunni jurisprudence. These covenants, wills, counsel, and ... were the political and social guidelines of the community, but in practice they did not have a operating guarantee (Afrough, 1998: 45).

Therefore, one can clearly conclude that there was no mechanism for imposing rulers on the rights of members of the community and the realization of citizenship, and most of the texts had guiding and advisory aspects. From the constitutional era, when our society became acquainted with the rules of civil life and prepared itself for its realization, meanings and perceptions very close to above concept were used by writers, poets and newspapers. The use of terms such as law, civil law, fundamental rights, social rights, natural law and the like have brought the culture of society to an awareness of the concept of citizenship. After the formation of a new civil law system at the end of the Qajar period in Iran, the term "national" in judicial and legal texts gradually replaced the term "vassal". In this sense, the aim was individuals, or those citizens who enjoyed state immunity or support in the face of adherence to, and compliance with, the rulings and decrees issued by them. After the Constitutional Revolution, even after the adoption of the Civil Code, the Iranian community was introduced from a legal point of view, a national, not citizens, of Iran (ibid., 51).

Thus, the use of the concept of a citizen could never have the support and acceptance of the civil rights of individuals in their comprehensive sense. Due to the general and cultural approach to the development of state and government rights and the lack of social space, the concepts of freedom, participation, enjoyment of social rights and many other similar and interconnected issues gradually coincided with the emergence of social and civil movements in the century and recent events in the country arose. The expansion of social and legal concepts requires the provision of the subjective and objective fields of society that we have less encountered in such a society in Iran. Certainly, our society has experienced resistance to the tyranny of the social and political life in various forms of social life in the long periods of its 
social life, but has never found itself sufficiently capable of transforming its real needs into fundamental legal and political issues. (Jahan Boglo, 1998: 26).

The undeniable historical fact about social rights was the massive and tumultuous nature of mandate duties against civil rights. In other words, the common culture of our society about the promotion of social rights has less tendency, and, on the contrary, mandate orders have grown more in the unequal aspect with civil rights in order to meet the demands of the states of the era. Such issues for the development of citizenship, as serious obstacles, must be given special attention (Mahdavianfar, 2013: 9). Due to the lack of social conditions and the dominance of sustainable political domination, the great Islamic teachings, which have various forms of individual, social, civil and personal rights, have not found the necessity for expansion and prosperity, although Shi'a jurisprudence, due to the attention of religious scholars, has detailed sections on describing the powers and duties of individuals regarding the affairs and the general life (Afrugh, 1997: 45).

\section{Investigating the status of civil rights of citizens in Iranian law}

In Iran's law, the constitution in Chapter III, titled "The rights of the nation," recognizes many of the individual rights and freedoms that are recognized in international human rights treaties and declarations. According to the twentieth article of this law, all people of the nation, including men and women, are equally protected by the law, and enjoy the human, economic, social and cultural rights, in accordance with the standards of Islam. In other principles of this law, other examples of human rights such as the right to life, dignity and honor, freedom to choose a job, the freedom of expression, the freedom of thought, fair trial, respect for private life, etc. are protected by the legislature. Black and other English-language legal dictionaries have defined civil rights as rights and freedoms of all citizens and residents of a community, without contact with an administrative or governmental organization, such as property rights, the right to marry, the right to equality before the law, the freedom to conclude Contract and trial by the jury and ... (Black, Henry, 1968: 680; Waldron, Jeremy, 1989: 63).

\section{The right to life of citizens}

The right to life is one of the innate natural rights of human beings, and this right is the basis of other rights and freedoms of citizenship, because all rights and freedoms are based on 
the living of human beings, and also The Universal Human Rights Declaration also states that everyone has the right to life, liberty and personal security (Tabataba'i Motmani, 1996: 29). Hence, preserving human life and non-aggression is not only necessary for any citizenship, but every state has a duty to respect the lives of its citizens, and endeavor very much to protect it from aggression (Abbasi , 2013: 58).

The right to life is a prerequisite for the enjoyment of the other rights and states that a person has the necessary right to live. The concept of life is also focused on issues such as law, politics, philosophy and ethics, as with issues such as the death penalty, torture, abortion, legitimate defense and warfare (Smagadi, 2014: 83). All human beings have the right to live, and no one can deny this right to man, except under the law, which is also applied in exceptional areas. Therefore, the deprivation of the right to live in human beings on the battlefield or the execution of criminals in countries that have the death penalty in their laws is one of the few cases that limits the above principle (Ghazi, 2009: 144). The Universal Declaration of Human Rights (1968), as the first international instrument for the protection of human rights, in its article 3, in a brief passage, recognizes the right to life as: "Everyone has the right to life, liberty and personal security" Amir Arjmand, 2001: 919).

\section{The right to security of citizens}

Security means that individuals remain immune from any rape or assault, such as murder, assault, imprisonment, physical and physical torture and other illegal punishment, in other words, any act that is related to human dignity, such as prostitution, exploitation and etc., which is not based on logical and legal criteria (Shabani, 2009: 119). Private security in Iran's constitution is generally the cause of judicial secrecy and personal immunity against offending others. Accordingly, in order to achieve the highest human dignity and freedom with responsibility for God, the Government of the Islamic Republic of Iran is required to ensure the full rights of individuals from men and women, and to establish a just judicial system for all and a public equality against the law. This is because the dignity, life, housing and occupation of individuals are inviolable, except in cases prescribed by law (art. 22). These matters can be interpreted in principle in Article 22 that these are essential and mutually exclusive, that is, aggression in each case constitutes an act of harassment to all of them and in fact an invasion of personal security (Malik, 2016: 50) . In the Declaration of Rights or Constitutional Texts, we usually find things that are aimed at creating private attributes of a person in the process of 
administering justice. This is because the individual appears before the court alone, and civil and political support should not have an effect on the top of the judiciary. Therefore, in the judicial system, mechanisms or guarantees must be foreseen and embedded so that individual loneliness in this system does not lead to insecurity of personal life and undermine the right to life (Poursayyed, 2008: 561-562).

\section{Investigating the Status of Citizenship Rights in Iran}

Legal systems are not a set of fixed norms that govern the relations of citizens and the state, but these norms, in a coherent framework, are always dynamic and expanding. Obviously, this dynamic is defined according to the operation of legal norms, which of course underscores one of these functions is the stability of the legal relations between citizens and the state, which, of course, is becoming more and more important for citizens. In other words, legal norms cannot be developed unconditionally, but one of the developmental axes should be to protect the interests of the rights activists, and consequently, citizens should be aware of their rights and duties and be able to anticipate the results of their legal acts (Vijeh , 2011: 96).

\section{The general guarantees of judicial security}

One of the pillars of good governance and achieving a desirable society is security at all levels and dimensions. One of the most important dimensions in providing comprehensive security in the judicial security community is, in other words, the general guarantees of judicial security. Certainly, a society cannot be found to be free of crime, and every tribe and society, in accordance with culture, has manners and qualities, which in the course of developments, advancements and various issues for its development, to become pregnant with the perpetrators of the offenses that are inevitable to tolerate them. In any case, also individuals in the community are also charged with these criminal acts and, accordingly, they may be harassed against the violations of the operators of law. So, these people should be secured with the judicial security mechanisms and these violations must be fought. Undoubtedly, the establishment of a competent justice system and the rule of law can be a major guarantee of the various threats to judicial security. On the one hand, the use of skilled and experienced law enforcement officers in detecting crime and observing the fundamental rights of the accused, such as the right to remain silent, the right to have a lawyer and its announcement to him, the 
prohibition of arbitrary arrest, the separation of prosecuting authorities and the need for their independence, the prohibition of the coercion of individuals and etc. ... can be one of the things that should be addressed. Also, in proceedings before the court, the principle of legality in all its aspects, the right to face trial, the due date, non-enforceability, and the opportunity of defense should be considered and after the issuance of the sentence, the principles governing punishments and the right to appeal and protest and his physical security in order to ensure judicial protection, in the strict sense, with regard to the defendants and the convicts should be used (Rahbar Farsh Pira, 2003: 23 -24).

The rule of law

In the term of our fundamental rights, the law is said to be passed by the Islamic Consultative Assembly in accordance with the rules established in Constitution Law, or passed directly through a referendum (Katouzian, 1995: 122). In fact, the law is a set of criteria that are general and inclusive, and in the same way as it flows on the commanders, it is imposed on the perpetrators. If the citizens do not escape from performance in the pattern of standards established by the government, the rulers and executive agents are also in a network of the same rules and regulations and must adapt themselves to its requirements (Ghazi, 43: 1992).

The Islamic Republic of Iran's constitution predicts its judicial security in the light of rule of law, that is, if individuals are prosecuted and pressed for acts contrary to the current law in the country, this imposition must be within the legal framework. Considering that actions are generally in the jurisdiction of the judiciary, it is possible to examine the rule of law with two principles (Farsh pira, 2006: 25).

Special guarantees for citizens' judicial security

Courts have been established to provide justice and resolve disagreements. Therefore, they should be sensitive in their performance and consider the foundation of their formation. Courts play the most important role in the realization of the goals of the judiciary, and in order to meet these goals more and more, it is necessary to adhere to some principles that ensure the health of proceeding and the justice of decisions in advance. For the judicial security of citizens, principles such as the presumption of innocence, the principle of openness of the proceedings, the right to a lawyer in litigation, the right to adequate facilities and sufficient time to prepare a 
defense, the principle of indictment of the accused, the principle of the prohibition of torture and other principles are guaranteed and we will consider the first four.

The presumption of innocence

Innocence is a practical principle whose content is based on the non-investigation of crime. According to this principle, if the commission of a crime in an accused person or persons is suspicious or doubtful, this principle requires that it has not be committed (Fakhar Tusi, 2012: 57). The presumption of innocence or assumption of innocence of the accused is the fundamental principle of a fair trial. This principle, which is included in the important international human rights instruments, is sometimes in line with other rights of the accused in the criminal proceedings and sometimes is stated in separate articles, is one of the cornerstones of the new criminal proceedings (Fazaeli, 293). The presumption of innocence was first formally introduced in 1789 in the Declaration of Human Rights of France, which states in Article 9 of the Declaration: "Persons are considered innocent until condemned." Among the authentic documents that have announced this principle, Article 2, paragraph 6, of the European Convention on Human Rights, Article 26 of the American Declaration of Human Rights and Duties, Article 8, paragraph 2, of the American Convention on Human Rights, Article 7, paragraph 1, of the African Charter, Article 7 of the Arab Charter on Human Rights, paragraph "i" of row "b", contained in article 40, paragraph 2, of the Convention on the Rights of the Child can be named, all of which are, in more or less similar terms, assigned to this principle.

\section{Investigating the status of Citizenship Political Rights in England}

Political participation reflects the individual's participation in political activities and the participation of people in making effective decisions on their situation. And if from this, the democratization process of politics can be understood implicitly, it is suitable that, in particular, from political participation the organized effort of the citizens to choose their leaders and influence the political direction of society in this regard be made (Mohammadi Asl, 2004: 18). 


\section{The Status of Citizens' Political Participation in the UK Legal System}

The diversity of environmental conditions and different approaches of thinkers has led to various definitions of political participation. The authors of sociology culture have defined political participation as part of the political process that leads to the choice of political leaders and determines or affects public policy. Michael Thrush considers the involvement of a person at various levels of activity in the political system, from non-involvement to political status, as a political participation (Michael Rash, 1998: 131).

Anthony Giddens considers political participation as a political right, and writes in the definition of political rights: "Participation rights, such as the right to vote in local and national elections, which have citizens and a certain community" (Shahbazi, 2001). : 59). Political rights and government participation are based on political freedoms. Whenever political freedoms are not recognized in the political system governing the community, there is no place and opportunity for citizens to enjoy political rights. Even if political rights are included in basic laws and ordinary laws, these rights are always subject to harm and damage. Political freedoms allow the people of a society to freely choose the type of their desire government and their representatives to participate in parliament or legislatures, freely criticize government policies, form associations and organizations and political parties, and join them (Mehrangiz Kar, Women's Political Participation, Barriers and Facilities).

The effects of citizens' political participation in the constitution law and election-related laws

Every citizen in every corner of the world has the right to participate in politics, to elect, to be elected and to work in the public sector.

The legal review of British citizens' the right to choose

By accepting the sovereignty of the people about their political and social destiny, their participation in the election of rulers is one of the obvious areas of this sovereignty, and the means of this participation are the right to provide them with the opportunity to choose their rulers. The right to vote is subject to the following conditions: 1 . The publicity of vote: By accepting that one of the hallmarks of democracy is universal participation, all residents, 
without any religious, sexual, economic or social discrimination, have a right to participate in the country, despite some restrictions, such as citizenship, age and bad record.

1. The equality of all people against the law requires that the right to vote is equal to everyone (Ghafari Anvar, 2011: 52).

2. The freedom of vote: For the popularity of the vote, the people should be free to vote, meaning that people are not required to participate or not to participate (Seyyed Mohammad Hashemi, 2005: 436).

One of the pillars of democracy is that, at the time of the election, people should be allowed to make the changes that they consider appropriate in the governing board. The changes are necessary in three respects: First, the agent may stay away from the wishes and aspirations of the people, or to avoid them, and, consequently, take a path contrary to will. Secondly, due to a sudden change in economic or political conditions, the society wants to go to parties or individuals who have opinions or ideas consistent with the new situation. Third, the participation of individuals in the election of the governing board teaches them every time, which is used in the next election. This course of evolution, although gradual, but its effects are well understood (Jafar Bushehri, 2005: 175).

The legal review of the right of British citizens to be elected and to engage in public employment

The title of democratic or democracy, which is the translation of a democratic term, is indicative of the headness of the people. Headness today means that people take some form of government and enforce political sovereignty. The exercise of political rule today takes place in a variety of ways, in which the representation mechanism in the world today is the most famous and perhaps the most efficient one (Gholamreza Khajeh Sarveyi, 22: 65).

\section{The legal review of how to ensure the judicial security of citizens in Britain}

In times of conflict between the freedoms and personal security of individuals and public security, sometimes balance is disturbed in the interest of public security. Watching the suspects by the police, without the authority of the judicial authority, is one of the most important and sometimes decisive steps in the criminal process in which the right to liberty and security of the person becomes a victim of public security. Consequently, international 
documents and domestic laws of countries have been designed to anticipate laws and regulations to regulate this stage of the criminal process and to ensure fair trial.

\section{The legal review of how to ensure the judicial security of citizens in the UK}

In the United Kingdom, the discretion of arresting individuals by ordinary citizens has been accepted in Article 24 of the Police and Criminal Code, which has been amended in accordance with Article 110 of the Police and Organized Crime Act of 2005 (Mehra \& Jahani, 2017: 36). In this respect, the British law have given the citizens at least the option of just arrest. The issue of the right to be informed in British law includes the subject of the charge and its justification, and does not include that place and the duration of possible follow-ups (Taheri, 2017: 45). In British law, according to paragraphs 1 and 2 of article 28 of the Criminal Code, the police are obliged to inform the individual immediately after arrest or at the earliest possible time. Otherwise, arrest will not be legal. Also, in Article 29, in the case of a person who is voluntarily present at the police station or where the police are present and then the police decide to arrest him, this task has been assigned to the police officer to inform him of his arrest and reasons (ibid, 2017: 45). The principles of criminal procedure are solid and stable grounds that prevent the diversion of justice from the path to justice. Dignified and innocent people who, without reasonable justification, are prosecuted, can eliminate the charges from themselves and restore their honor. The principles of the trial, such as the principle of equality of persons against the law and the courts, the principle of openness of the proceedings and trial, the principle of legality of the proceedings, the principle of twofold jurisdiction and the presumption of innocence, are accepted throughout the history of the procedure of prosecution in human societies.

\section{Entities guaranteeing and overnighting civil rights in Iran's constitution and British law}

The Iranian Civil Code states in Article 959: No one can generally deny the right to benefit or exercise all or part of civil rights from himself.

The realization of criminal justice has always been and is a desire for justice for all human beings throughout history. Without a doubt, respect for criminal justice, without fair trial, in which the rights of citizenship and the freedoms of the people of the community are 
respected, will never have chance to emerge. On the other hand, one of the factors of the development of the criminal justice system in the present era is the concepts and criteria of civil rights. These concepts and criteria, identified and protected in international and regional documents, have been particularly effective in the enforcement of national criminal laws and regulations. The most striking effect is the civil rights or legal guarantees of the defendant against the police and judicial authorities. Hence, the implementation of criminal justice in civil society is indispensable in protecting and protecting the rights of citizens; because the enforcement of criminal justice is also in the direction of protecting the rights of citizens, in order to prevent the perpetrators from violating their rights or those who have the basis for committing offenses and antisocial behaviors, should be prevented from the occurrence and appearance of these behaviors by taking preventive measures (Gholami and Gholami, 2011: 102).

\section{Monitoring entities on Citizenship Rights in Iran}

General and Revolutionary Courts, The commission of Article 90 of the Islamic Consultative Assembly, the Administrative Justice Court, and The General Inspection Organization of Iran (GIO) are observing the rights of citizens in Iran.

General and Revolutionary Courts

The Islamic Revolutionary Court, formed on March 5, 1979, by the founder of the Islamic Revolution, Imam Khomeini (RA), after the adoption of the constitution of the Islamic Republic of Iran, became one of the judiciary courts of the Islamic Republic of Iran which has inherent jurisdiction over other courts of justice. General Courts are courts that have the right to handle all claims and disputes, except as provided by the law in another jurisdiction. The general court is formed by the appointment of the head of the judiciary in the centers of sections, cities, and certain points of the big cities. According to Article 4 of the Law on the reform of the formation of public and revolutionary courts in approved in October 2002, in each jurisdiction, where the general court has more than one branch, branches are divided into legal and punitive. The legal general court only deals with legal affairs, and criminal courts deal only with criminal cases. Of course, in cases of necessity, the legal court addresses criminal cases and the criminal court addresses legal matters. In this regard, it should be noted that according to 
the law "The formation of the family court", adopted on March 8, 1997, a number of general court branches were assigned to family cases, and then other branches of the general court would not have the right to sue family litigation (Shams, 2007: 56 and Mardani, Nader and Beheshti, Mohammad Javad, the former, 27).

The commission of Article 90 of the Islamic Consultative Assembly

The commission of Article 90 is one of the specialized committees of the Islamic Consultative Assembly, which performs the duties entrusted to the Assembly in Article 90 of the Constitution of the Islamic Republic of Iran. The principle states: "Anyone who has a complaint about the work of the Assembly or the executive branch or the judiciary, can submit his complaint in writing to the Islamic Consultative Assembly. The parliament is required to handle these complaints and give them adequate answers and in cases of complaint to the executive branch or the judiciary, they will be required to respond to them and within a reasonable time, declare the outcome and publicize the matter that is public.

\section{Administrative Justice Court}

Under Article 173 of the Constitution, the Administrative Justice Court was established under the supervision of the judiciary in order to deal with complaints, litigation and protests of people against the officers or government units or regulations. (Bahrami, 2006: 87). Under the new law and the procedure of the Administrative Justice Court, approved in 2014, general and administrative unilateral obligation, such as regulations and directives, in the case of illegal, non-religious and extrajudicial authority, is a setter reference subjected to review and cancellation in the General Board of the Administrative Justice Court. On the other hand, bilateral contractual actions also form an important part of the administrative operation of executive agencies. Many of these contracts, such as selling, mortgages and leases, are contracted to meet the needs of the government with private individuals and are subject to the rules of private law. And the existence of public law individuals does not change the rules governing the relations between the parties. Therefore, if there is a difference in the interpretation and implementation of the provisions of such contracts, the general courts, in accordance with the general jurisdiction that Article 159 of the Constitution have identified for them, are competent to deal with (Shirzad and Mahmoudian Isfahani, 2017: 26). 
The General Inspection Organization of Iran (GIO)

The General Inspection Organization of Iran (GIO) is one of the Iranian judiciary bodies formed in order to implement Article 174 of the Constitution of the Islamic Republic of Iran. The activities of the General Inspection Organization of Iran are under the supervision of the head of the judiciary. This organization is a security agency. According to Article 2 of the law of establishment the organization, its duties are as follows:

1. Continuous inspections of all ministries, departments and military and police forces and state institutions and companies and municipalities and their affiliated organizations, and non-governmental and public institutions, and revolutionary institutions and organizations in which all or part of their capital or shares are owned by the government or the government in any way oversees or assists them, and any organizations that inclusion of this law in relation to them, according to the regular schedule, requires the mention of their name (Parvin and Delbar, 2015: 129).

2. Exercising extraordinary inspections, in accordance with the order of the Supreme Leader, at the behest of the head of the judiciary, the request of the President, the Commission on Principles 88 and 90 of the Constitution of the Islamic Consultative Assembly, at the request of the Minister or the head of the relevant executive bodies, or any item deemed necessary by the chairman of the organization.

3. The declaration of violations and administrative and financial malfunctions concerning the ministries and institutions of the Islamic Revolution and foundations to the President and in relation to institutions and affiliates of the Government to the relevant minister and in the case of the municipalities and institutions affiliated with the Minister of the Interior, and regarding the non-governmental organizations receiving help from the government to the Ministry of Economic Affairs and Finance, and regarding administrative and financial abuses of the judicial authorities and subordinate units of the judiciary to the head of the judiciary, and in the referral cases of the Commission of Principles 88 and 90 of the Constitution, the commission will be notified of the outcome of the inspection (Parvin and Delbar, 2014: 129). 


\section{The monitoring institutions of civil rights in the UK}

The English court system today is largely influenced by the laws of 1873-1877. In general, courts in England can be divided into two parts: criminal and civil.

\section{UK Criminal Court}

The duty of the criminal system is the enforcement of criminal justice and the recognition of the public rights of individuals in society. Until 1880, there was no government body in England to prosecute crimes, and criminal complaints of individuals were brought directly or through their lawyers in court. Factors such as population growth, the effective actions of the police force, organizational growth of central government, and the political and philosophical development of the phenomenon of human freedom and the need to preserve the individual's freedoms of the convict and the victim necessitated the establishment of a public and governmental body for prosecute criminal offenses and a public prosecution institution was formed in 1880 and the first chairman of that institution was appointed that year. In fact, this institution was created to prevent injustice and abuse of justice in peace courts, known as police courts. In 1978, the interior minister commissioned a special commission to investigate the criminal prosecution system. That commission declared the penal system inadequate, because of the inappropriate nature of the police force in expressing accusations against individuals and adopting different and controversial policies in different parts of the country by the police to prosecute or not prosecute offenders and lay down very weak criminal cases against judges and suggested that an independent public body be formed in accordance with the law adopted by the parliament. Following the proposal, the law of 1985 called the Prosecution of Crimes Act was approved by Parliament, and since October 1, 1986, the Public Prosecutor's Office for the Prosecution of Crimes throughout the United Kingdom has begun. At the head of the institution, the Attorney General is the country's highest legal authority and the head of the institution and is responsible for the enforcement of criminal laws in the United Kingdom and provides the government with independent legal advice.

\section{Criminal investigation court}


This court has a local dimension and usually deals with light crimes. Most of the crimes that are being investigated in this court are related to driving and small-scale robbery (Mirghammad Sadeghi, 1997: 135).

The criminal court of appeal

The criminal courts of appeal are two types: a number of them work as criminal courts of appeal, and some work as branches of the Queen's court. The criminal court of appeal consists of three prominent judges, namely, the head of the judiciary, the chairman of the criminal court of appeal and the judges of the queen's court, and the court is credible with the presence of three judges. This court will review the judgment of the king court that is being challenged and does not have the right to exacerbate the punishment.

The Queen's court also reconsidered the other types of the judgments of lower courts. In this way, two of the Queen's court judges will examine the appeal of one of the parties, the prosecutor or the accused, about non-compliance with the law. The prosecutor or the accused can ask the King's court to send the report to the court for the opinion of the Queen's court. The King's court, in writing, sends the case description and its reasons and the basis of its decision to the Queen's court branch, and the Queen's court issues a ruling on the same basis.

European Convention on Human Rights

The first human rights document at the regional level is the European Convention for the Protection of Human Rights and Fundamental Freedoms, which was adopted by the former members of the Council of Europe on November 4, 1950, and was enforced on September 3, 1953. The convention is also the first human rights document that has predicted a judicial body, that is, the European Court of Human Rights in Strasbourg, as a regulatory mechanism for enforcing its rules. Subsequently, the Human Rights Convention was re-examined in 1998. One way in which one goal should be pursued is to preserve and enforce human rights and fundamental freedoms and reaffirming their deepest belief in these fundamental freedoms, which are the basis of peace and freedom in the world and they are best preserved, on the one hand, through effective political democracy, and on the other hand, through the common understanding and observance of the human rights that they depend on, and, as governments of European countries that have the same thought and have a common heritage of political 
custom, desirable goals, freedom and the rule of law, are determined to take the first steps for the collective implementation of the rights set forth in the Universal Declaration (Taqi Pour, 138: 115-114).

The European Convention on Human Rights, with the entry into force of Protocol No. 11 in 1998, entered a new phase in its life. According to Article 27, the court will have committees consisting of three judges and a branch consisting of seven judges and a high-ranking branch of seventeen judges, including the head of the court and his deputies (Qari Seyyed Fatemi, 2000: 138). One of the positive points raised in article 34 of the convention are that individuals, regardless of their nationality, have the right to go to the court. Therefore, citizens of nonnationals of the States Parties may also sue a court for violations of rights set forth in the Convention by one of the States Parties of the Convention.

Civil Rights Courts (Division)

General Courts are categorized as follows:

Division or legal court

The court was formed under the District Court Law, adopted in 1846, to resolve the quick and cheap civil disputes locally. Some of the principles in these courts are also found in the 1971 law of courts. The workload of these courts depends on where it occurs, that is, when a legal court is located near one of the big cities, it usually has to hold a meeting every day and has three or four judges to deal with all the cases (Mir Mohammad Sadeghi, 1996: 128 -129).

County or legal court

With each of the seventy judges of the legal court, a legal court can set up in London or elsewhere in the country. The court, although under the laws of 1873-1875, has been formed, its current form is affected by the 1970 law of justice.

Research Court-Civil Branch

The court was formed according to the judiciary laws of 1873-1873, but its current form is influenced by the Criminal Investigation Act of 1966. The civil division of the court treats appeals from the legal court decisions and some special courts, such as the trial of the land, the 
employment research tribunal, and the like. The research court consists of eight to eighteen judges of research. In this case, in exceptional cases, a judge will deal with a lawsuit, but usually a court is composed of 3 to 5 judges. The only venue for the formation of this court is the Royal Courthouse, built in 1874 on the basis of the thirteenth century architecture and located in the Strand area of London (Mir Mohammad Sadeghi, 2017: 132).

The House of Lords

In all cases, with the exception of those claims in relation to the laws of the common European Community, the last court is an appeal court. The court's decisions are binding on the lower courts and can only be changed by the law or, in some cases, by the court itself. In the House of Lords there are a total of 7 to 11 judges, and this is the final court of reference for appeals for cases heard in the Scottish and Irish courts. Two of these judges are usually from Scotland and one from Ireland. For the purpose of seeking research from the House of Lords, first the permission of the Research Parliament or Court should be taken. Usually this permission is given to those litigations that are of public importance. In criminal matters, appeals to the House of Lords are not accepted for the facts of the lawsuit, but only for legal principles and rules. In practice, the research requests that are given to the House of Lords are usually about how the laws are interpreted (Mir Mohammad Sadeghi, 2017: 134). The highest judicial body of criminal appeals is the House of Lords, whose Judicial Committee reconsiders the opinions of the Criminal Appeal Court and the verdicts of the branch court of Queen's court of appeals, and each prosecutor of accused can appeal to the House of Lords, provided that the criminal appeal court or the branch court of Queen's court of appeals prescribe appeal on the basis that their decisions about appeal are related to significant public subjects. The House of Lords is composed of three judges, including the head of the judiciary, lawyers, and other highranking judges. The court is attended by three judges and each judge expresses his opinion separately and votes are valid by a majority of votes.

\section{CONCLUSION}

Citizenship rights are the rights that citizens enjoy in terms of political affiliation, citizenship and nationality, and thus overlap with human rights, because the root of citizenship rights should be sought in human rights. In fact, human rights relate to human rights, regardless 
of its temporal and spatial position, which includes civil, social and political rights. In terms of Islam and the laws of Iran, citizenship rights of all people have been respected and the right to life and the right to freedom and equal rights to all human beings, both Muslims and nonMuslims, are obligatory. In the sense of citizenship, appropriate rights and duties are considered for each citizen at the same time. On this basis, citizenship rights, while providing a set of rights for citizens and recognizing them without any exceptions, are considered as a duty for them, which they must deal with them. On the other hand, these rights and duties are correlate each other, and no one can be imagined without the other. Basically, today's citizen is the one whose duties determine his rights, and for this reason, a desirable citizen is a citizen who has responsible behavior, that is, he is liable to his rights. The system of citizenship, in its true sense, means that all members of society are entitled to equal rights and duties, in such a way that there is no political, social, and civil rights discrimination among people of the society.

In political law, the rule of law is the imperative of the realization of democracy, and that is when the law comes from the rule of the people. That is, it should be formed through inclusive elections, with the participation of all segments of the people and legislative institutions that are at the highest level of the hierarchy of the public organizations of this institution and the governing law is the result of the work of this legislative institution. In addition, this law should be issued from such an authority and prominent in the society. Notable in this regard is attention to the compliance of political authorities with the law, meaning that all government actions should be placed within the constitutional framework and that the rulers should be responsible for their actions. At the same time, the guarantee of the rights and freedoms of citizens and the establishment of security for them depends on the regulation of the authority of the governing body through the establishment of the law, which rationally specifies the limits of their authority. Even these rules require special qualifications to qualify. Meanwhile, shared human experiences also point to the important thing that human dignity depends on the protection of individual and collective rights, social, political, cultural, and economic rights, and the respect for individual and collective freedoms. Some of the fundamental principles of human life are both rational and religious. Citizenship rights are one of those areas that are respected by all and confirmed by Sharia and wisdom. Therefore, they are less doubtful and controversial.

With regard to the criminal and judicial rights of citizens both in Iran and in the United Kingdom, the rights and freedoms of citizens are their rights and the duty of the state, and it is the duty of the state to adopt various measures for this important matter. The constitution, the 
Islamic Penal Code, and the Iranian criminal procedure protect the rights of citizens and the freedoms of the people to the best of their ability, but in terms of criminal guarantee, both about the deprivation of the rights of ordinary citizens and the deprivation of the rights of defendants who need more criminal support for violations of rights, Iran's criminal policy has significant shortcomings. The criminal procedure law contains provisions that are closely linked to the rights of citizens. In England law, theoretically, there is no strong boundary between police and citizenship' arrests, and, according to the ideas of Kamenla, police act as a citizen to maintain order. This principle is rooted in the historical context and culture of the people of this country. Now, the right to arrest is considered in comprehensive regulations for English citizens and in crimes with indictment and in two-face crimes which, other than micro-crimes, cover many charges, ordinary people can arrest a person when doing a crime or for reasonable reasons, accused of committing a crime. Therefore, and contrary to police powers, on the assumption that the person has not yet commenced criminal offenses, citizens do not have the right to interfere on the pretext of preventing crime. Also, the scope of action and legal responsibilities of citizens in the event of a mistake in arrest or extra-judicial action are precisely defined in the law or judicial process of this country.

\section{REFERENCES}

THE HOLY QURAN

A-PERSIAN BOOKS

ISMAGADI, Afroniyeh, 2013, Reference Document for International Human Rights, Translated by Reza Islami, Tehran: Khorsandi

AFROUZ, Imad, 2008, Citizenship and Justice Rights, Tehran: Sureh-e- Mehr

AMIR ARJMAND, Ardeshir, 2001, The Collection of International Human Rights Documents, Tehran: Shahid Beheshti

BUSHEHRI, Jafar, 2005, Basic Law, Principles and Rules, Tehran: Entesharco

Bushehri, Jafar, 2005, The issues of Basic Law, Tehran: Dadgostar

JAHANBEGLOO, Ramin, 1997, Modernity of Democracy and Intellectuals, Tehran: Center

SHA'BAN, Qasem, 2009, Basic Rights and Structure of the Government of the Islamic Republic of Iran, Tehran: Ettela'at Publication 
TABATABA'I MOTMENI, Manouchehr, 2009, General Freedom in Human Rights, Tehran: Tehran University

ABBASI, Bijan, 2011, Human Rights and Fundamental Freedoms, Tehran: Dadgostar

FALOX, Keith, 2003, Citizenship Translated by Mohammad Taghi Delfrooz, Tehran: Kavir

QARI SEYYED FATEMI, Mohammad, 2001, The concept of citizenship in the legal system of Iran, International Conference on Human Rights and Dialogue of Civilizations, Tehran

GHAZI, Abolfazl, 1992, The Requirements of Basic Law, Tehran: Mizan

KATOUZIAN, Nasser, 1994, The Principles of Public Law, Tehran: Dadgostar

MICHAEL, Rash, 1998, Society and Politics, Translated by Manouchehr Sabouri, Tehran: SAMT

MOHAMMADI ASL, Abbas, 2004, Gender and Income Contribution to the Sociology of Political Participation of Iran, Tehran Tehran

Gender and Participation, an Introduction to the Sociology of Political Participation in Iran,

HASHEMI, Mohammad, 1996, The Basic Law of the Islamic Republic of Iran, Tehran: Dadgostar

PARVIN, Khairullah and Delbar, Hossein, 2014, Evaluation and Correction of the Administrative Process in the Mirror of the General Inspection Organization, Journal of Public Law Research, N. 42, pp. 11-140.

TAGHIPOUR, Sirous, 2011, Iranian Citizens Rights and Judiciary. The Trial Monthly, No. 89.

KHAJEH SARVEYI, Gholamreza, Democratic Political Consolidation, Islamic Azad University Journal, No. 22

RAHBAR FARSH PIRA, Nasser, 2006, Judicial Security and Citizen's Rights, The Journal of the Bar Association, No. 3 and 4, pp. 21-36

SHAMS, Abdullah, 2002, The Principle of correspondence, the Journal of Leg Shirzad and Mahmoudian Esfahani, 2017, Examining the jurisdiction of the Administrative Justice Court in disputes arising from administrative contracts, the Journal of Lawyers, No. 9, pp. 25-38.al Investigations, No. 35, pp. 59-86.

SHIRZAD AND MAHMOUDIAN ESFAHANI, 2017, Examining the jurisdiction of the Administrative Justice Court in disputes arising from administrative contracts, the magazine of law scholars, No. 9, pp. 25-38.

TAHERI, Samaneh, 2017, The Comparative study of the rights of the person under observation in the Criminal Procedure Code of Iran and the United Kingdom, Karagah Magazine, No, 38, pp. 3863 
OLIYA, Sajedeh, 2011, The Place of Citizenship Rights in the Achaemenid Age, the Quarterly Journal of Excellence in Law, No. 13 and 14

GHAMAMI, 2008, Mohammad Mahdi, Dissertation of General Order and Requirements Caused by Human Rights and Citizenship Rights, Imam Sadegh University

VIJEH, Mohammad Reza, 2011, Legal security as a condition for the implementation of judicial security, Rahbord Quarterly Journal, No. 58, pp. 95-120

\section{DISSERTATION}

GHAFARI ANVAR, Attieh, 2011, "The Comparative Study of the Status of Citizenship Rights in Iran and France", Supervisor: Dr. Roya Motamednejad, Allameh Tabataba'i University, Master's Degree, General Law.

GHOLAMI RAZINI, Mohsen and Gholami, Hossein, 2011, "Citizenship Rights in the Criminal Justice Process of Iran", the Journal of Disciplinary knowledge, No. 52, pp. 101-134

MALEK, Mohammad, 2016, "the Comparison of Citizenship Rights in the Constitution of the Islamic Republic of Iran and the Citizenship Rights of England", Supervisor: Dr. Reza Islami, Master's Degree in Public Law, Azad University of Tehran Center

MAHDAVIANFAR, Masoud, 2012, "Obstacles to the Development of Citizenship in Iran from the Constitutional Revolution so far", Supervisor: Dr. Mohammad Ali Tavana, Master's degree in Political Science, Yazd University.

Trabalho enviado em 09 de abril de 2018.

Aceito em 13 de maio de 2018. 